\title{
Ageism: Discrimination that Must Disappear.
}

\begin{abstract}
Introduction: Ageism or old age is a very old concept and refers to negative stereotypes and prejudicial attitudes toward old age and how these are reflected in psychological and social problems.

Discussion: Ageism has been identified as the third major form of discrimination in our society after racism and sexism. Robert Butler coined in 1969 the term "ageism" to refer to the set of negative attitudes towards the elderly, social stereotypes, of prejudice and discrimination, maintained by the population to the detriment of old age and the aging process as a cycle of life associated with illness, suffering and loneliness, based on the belief that aging makes less attractive, sexual and productive people.

Conclusion: Strategies that combat ageism consist of creating intergenerational teams and organizing campaigns to challenge myths and wrong stereotypes that hinder the ability of older people to participate.
\end{abstract}

\section{Introduction}

The aging of the population is a process without parallel in the history of mankind. Currently the population is aging not only in the developed world, but across the planet, gradually, according to the latest report by the Population Division of the United Nations [1]. Since 1950 the proportion of adults over 60 years has been steadily increasing worldwide; the elderly population increases by $2 \%$ per year, considerably faster than the total population [2]. According to the prospects of the United Nations Organization, this age group will increase from $8 \%$ in 2008 to $14 \%$ in 2025 and to $23 \%$ in 2050 [3].

Developing countries as Mexico, is in a demographic transition in which the aging of population, initiated some years ago, will accelerate significantly in the next 20 years, being one of the social phenomena of greater impact of the present century [4].

The rate of older adult increases in size at a rate that doubles the rate of population growth in the country and the number of older adults has tripled since 1970 to date [5]. It has been reported that between 2000 and 2006, the elderly population grew by $20 \%$, according to the National Council estimations. The aging process of the population is a reality that in the world has Prouced important changes that would results in adjustments at different levels, such as demographic structure, economy and social and family relations; among others [6]. This perspective requires an understanding of the characteristics, determinants and consequences of this demographic change over time, with particular reference to developing countries [7].

The study of the aging process also poses theoretical and methodological challenges; as it is well known that there is no single paradigm of aging. Old age refers to a multifaceted reality, determined by longevity, which also involves physiological, social and cultural factors that are determining factors in the way of that process [8].

Ciceron, in his "De Senectute" defines old age, emphasizing that the intellectual faculties of the elderly, passed through the filter

\section{Journal of}

Geriatrics and Palliative Care

\author{
Sierra-Ayala I, Gutierrez-Herrera R, Riquelme- \\ Heras $H^{*}$, Gomez-Gomez C and Ordoñez-Azuara $Y$ \\ Department of Family Medicine, Universidad Autonomy de Nuevo \\ Leon, Mexico

\section{*Address for Correspondence} \\ Riquelme-Heras H, Department of Family Medicine, Universidad Autono- \\ my de Nuevo Leon, Mexico; E-mail: riquelme@doctor.com \\ Submission: 04 November, 2017 \\ Accepted: 05 December, 2017 \\ Published: 08 December, 2017 \\ Copyright: (๑) 2017 Sierra-Ayala I, et al. This is an open access article \\ distributed under the Creative Commons Attribution License, which \\ permits unrestricted use, distribution, and reproduction in any medium, \\ provided the original work is properly cited.
}

of prudence, dignity and moderation are an important asset that benefits the whole society [9]. In the Old Testament there is also abundant evidence that one of the main signs of divine favor is the senescence [10].

The Pan American Health Organization (PAHO) says that aging is the process of integration between the aging individual and a contextual reality in a permanent process of change. It is important to highlight, that a person is considered to be older when he/she reaches the age of 60-65 years old; this is regardless of his/her medical history and the particular situation in which he/she is located [11].

\section{Discussion}

There are various synonyms used to describe older people, such as elderly, elder, elderly person, geronto, decrepit, senescent, old, aged and so on. The word "old" almost always has negative connotations, usually related with terms such as disability or dementia. Traditionally it has been argued that in Western societies there is a fundamentally negative view of aging and older people [12]. The negative assessment of aging has the following connotations: physically, the person is diminished; mentally, it is deficient, is economically dependent, is socially isolated and has a decline in social status.

Several of the early research on aging focused on an alleged negative view of old age. These investigations, while seeming to support this assumption, demonstrated that accepting that there is a unilaterally negative perception of old age or elderly, is an overly simplistic conclusion $[13,14]$. The issues concerning old age are themes surrounded by myths and stereotypes throughout the history of mankind [15].

Ageism or old age is a very old concept and refers to negative stereotypes and prejudicial attitudes toward old age and how these are reflected in psychological and social problems. Ageism has been identified as the third major form of discrimination in our society after racism and sexism; (Stallard) (Craig) [16,17]. Robert Butler coined in 1969 the term "ageism" to refer to the set of negative attitudes towards the elderly, social stereotypes, of prejudice and discrimination, maintained by the population to the detriment of 
Citation: Sierra-Ayala I, Gutierrez-Herrera R, Riquelme-Heras H, Gomez-Gomez C, Ordoñez-Azuara Y. Ageism: Discrimination that Must Disappear. J Geriatrics Palliative Care 2017;5(1): 3.

ISSN: 2373-1133

old age and the aging process as a cycle of life associated with illness, suffering and loneliness, based on the belief that aging makes less attractive, sexual and productive people $[18,19]$. This type of attitudes is present in Western society today (Pal more), probably even more as sexism and racism [20]. For Salvarezza ageism is a complex behavior, determined by the population to consciously and unconsciously devalue the social status of the elderly [21].

However, ageism can be positive, when the attributes of age are judged advantageously or when you think of the romantic stereotype: the elderly of gray hair, retired, at home, with his/her grandchildren, gardening, resting from a lifetime of work. However, most studies of ageism attitudes tend to focus on their negative aspects. The disease, decline of skills, isolation and deteriorating of mental state according to Pal more are the most influential unfounded prejudices at this stage [22].

In fact, the age-based biases provide an image of old age, mainly based on negative traits favoring the development of professional discriminatory practices, building in an inaccurate, false, fatalistic and retrograde old age, associated to innumerable physical, psychological and social deficits as a preconception engendered in popular knowledge $[23,24]$. These age-related bias towards older people are found in both young people (Montañés), and in middle age groups (Chasten) [25,26].

Ageism socially generates a unidimensional vision, which is transmitted from generation to generation and condemns old age to a period of involution, where there is a rupture of values and resentment to everything that reflects old age. Inaccurate images can lead to negative consequences to harmful stereotypes and discriminatory practices to this population group.

The Spanish Confederation of Elderly Organizations (CEOMA) recognizes that discrimination against the elderly is the third cause of discrimination [27].

Age discrimination is more noticeable at work although older workers are not necessarily less healthy or skilled or productive than their young colleagues. Older women face the dual problem of discrimination due to sex and age.

Anti-discriminatory laws have been adopted in a number of countries to combat discrimination based on age. In the European Union, Directive 2000/78/EC establish as a general framework for equal treatment in employment and occupation [28].

The United States has one of the highest rates of participation of people over 65 in the labor market. They have one of the strongest anti-discrimination systems. The Age Discrimination in Employment Act of 1967 prohibits employment discrimination against persons 40 years of age or older [29].

Although in the United States there is discrimination in adult residences, which is reflected in poor health care for these people, little economic support for the government and few staff [30].

\section{Conclusion}

Studies are needed to investigate the effects of work collaboration between young people and older adults in order to combat stereotypes about this age group.
Strategies that combat ageism consist of creating intergenerational teams and organizing campaigns to challenge myths and wrong stereotypes that hinder the ability of older people to participate.

Policies to treat all citizens with respect, including those in institutions, are required to be rooted in society and enforced.

Actually it is very important to combat the age-old stereotypes and myths that are doing a lot of damage to older adults and society, and remember that we could all suffer from this problem and come under the consequences.

The world needs to value elderly people. It is mandatory to transmit values from generation to generation to youth to respect their elders.

Children and youth should receive an education focused on respect for the elderly and inculcate respect for the knowledge generated by life experience. Probably, this is the way to reverse the stereotypes that currently exist for ageism.

\section{References}

1. World Population Ageing 2007 (Sales No. E.07.XIII.5, ISBN 978-92-1151432-2).

2. United Nations (2002), World Population Ageing: 1950-2050, New York, Population Division, Sales N E. 02. XIII. 3.

3. United Nations (2002), World Population Ageing: 1950-2050, New York Population Division, E.02.XIII.3. (2001), Population Bulletin of the United Nations: Living Arrangements of Older Persons: Critical Issues and Policy Responses, New York, Sales No E.01.XIII.16.

4. CONAPO (2002). Projections of the population of Mexico 2000-2050. México.

5. Mexico DF (2005) There will be about 8.2 million elderly people in Mexico by mid-2005. Press release 04 / 05

6. World NGO Forum on Aging (2002) Proposals and recommendations for action for governments and civil society. Madrid pp: 1-4.

7. Frenk J (1994) La salud de la población: hacia una nueva salud pública México: Fondo de Cultura Económica.

8. LATINO AMERICANO (2010) Centro; DE DEMOGRAFÍA, Caribeño. Manual Sobre Indicadores de Calidad de Vida en la Vejez. Santiago de Chile. 2006.

9. (2016) Marco Tulio Cicerón - De Senectute.

10. Hall GS (1922) Senescence, the last half of life. New York: D. Appleton and Company 1844-1924.

11. Bonita Ruth (1988) WHO: Women, Aging and Health: Achieving Health across the Lifespan ( $2^{\text {nd }}$ Eds). Ginebra pp: 55.

12. Levin J, Levin WC (1980) Ageism: Prejudice and discrimination toward the elderly. Belmont, CA: Wadsworth pp: 153.

13. Tuckman J, Lorge I (1953) Attitudes toward old people. Journal of Social Psychology 37: 249-260.

14. (1992) Washington: The National Council on Aging. Fernández-Ballesteros, R. Mitos y realidades sobre la vejez y la salud. Barcelona: Fundación Caja de Madrid.

15. Feliciano V (1997) Construcción y evaluación en diferentes cohortes del DSE (Diferencial Semántico del envejecimiento). Anales de psicología 13: 31-37.

16. Stallard JM, Decker IM, Sellers JB (2002) Health Care for the Elderly: A Social Obligation. Nurs Forum 37: 5-15.

17. Craig GJ, Baucum D (2001) Desarrollo psicológico. Pearson Educación.

18. Butler RN (1969) Age-ism: Another form of bigotry. Gerontologist 9: 243-246. 
Citation: Sierra-Ayala I, Gutierrez-Herrera R, Riquelme-Heras H, Gomez-Gomez C, Ordoñez-Azuara Y. Ageism: Discrimination that Must Disappear. J Geriatrics Palliative Care 2017;5(1): 3.

ISSN: 2373-1133

19. Atchley RC (1997) Social forces and aging: an introduction to social gerontology ( $8^{\text {th }}$ Eds). Belmont, CA: Wadsworth pp: 589.

20. Erdman $P$ (2001) The ageism survey: First findings. Gerontologist 41: 572 575.

21. Leopoldo S (2002) Psicogeriatría: teoría y clínica. Paidós.

22. Erdman P (1999) Ageism: Negative and positive (2 ${ }^{\text {nd }}$ Eds). Springer Publishing Company

23. Rodríguez JM (1998) Actitudes hacia las personas mayores y discriminación basada en la edad. Revista multidisciplinar de gerontología 8: 21-30.

24. Ballesteros RF, Montorio I, Hernández López JM, Gema Llorente GM, de Trocóniz Ml, et al. (1992) Myths and realities about old age and health. Barcelona: Caja de Madrid Foundation.

25. Montañés J, Latorre JM, de la Vejez P (2004) Youth stereotypes about aging
Psychology of Old Age (youth stereotypes about aging). Cuenca: Editions of the University of Castilla-La Mancha.

26. Chasteen AL, Schwarz N, Park DC (2002) The activation of aging stereotypes in younger and older adults. The Journals of Gerontology Series B: Psychological Sciences and Social Sciences 57: 540-547.

27. Ageism, third major discrimination in Spain.

28. Council of the European Union; Council Directive 2000/78 / EC of 27 November 2000 on the stablishment of a general framework for equal treatment in employment and occupation.

29. U.S. Equal Employment. Opportunity Commission. The Age Discrimination in Employment Act (ADEA).

30. United States General Accounting Office, Nursing Home Quality: Prevalence of Serious Problems Reinforces Importance of Enhanced Oversight, GAO03-561 (Washington: United States General Accounting Office, 2003). 